\title{
The Existence of human resources employability to energize the power of competitive advantage of aqiqah Nurul Hayat Surabaya
}

\author{
Johny Rusdiyanto \& Elsye Tandelilin \\ University of Surabaya, Surabaya, Indonesia
}

\begin{abstract}
This paper examines the importance of HR employability and their relationship with employment within the food industry in Indonesia, specifically in Aqiqah business services. This is a review of the literature related to the provision of HR empowerment program to sustain business competitiveness and economic growth in Aqiqah business services. The effects of organizational culture are examined to address the employees' behaviors concerning the fairness of treatment, trust, and delivery of promises. This review was undertaken to explore the significance of skill shortages and skill mismatches. The paper suggested that the role of HR Empowerment program schemes to ensure for employees' employability as dynamic capabilities action deeply, along with positive employment relationships, are the key to support Aqiqah business services in dealing with a competitive advantage
\end{abstract}

Keywords: employability, competitive advantages, dynamic capabilities

\section{INTRODUCTION}

Nowadays, markets are increasingly anxious with globalization, rapid changes in technologies and highly intense and competitive industry. As a result, employers now tend to concern more about finding suitable employees with high employability to adjust with rapid changes in the industry (Stiwne \& Jungert 2010, Howieson et al. 2012, Sahandri et al. 2012, Sattar et al. 2012, Yahya et al. 2013, Fong et al. 2014 In business, where the competitive landscape is shifting, the dynamic capabilities by which firm managers 'integrate, build, and reconfigure internal and external competencies to address rapidly changing environments' (Teece et al. 1997) become the source of sustainable competitive advantage. The manipulation of knowledge resources, in particular, is especially critical in such business (Grant 1996, Kogut 1996).

Since dynamic capabilities are processes embedded in firms, we assume an organizational and empirical lens, rather than an economic and formal modeling one (Barney 1991, Peteraf 1993). We examine the nature of dynamic capabilities, how those capabilities are influenced by market dynamism and their evolution over time. Employability is the possession by an individual of the qualities and compe- tencies required to meet the changing needs of employers and customers and thereby help to realize his or her aspirations and potential in work (CBI 1999). Employability signifies the development of skills and adaptable workforces in which all those capable of work are encouraged to develop the skills, knowledge, technology, and adaptability to enable them to enter and remain in employment throughout their working lives. According to Schreuder \& Coetzee (2011:48) employability refers to an individual's capacity and willingness to become and remain attractive in the labor market, also the individual's capability to be successful in a wide range of jobs. Employability is having a set of skills, knowledge, understanding and personal attributes that makes an individual more likely to choose and secure jobs in which they can be satisfied and successful. Career resilience plays an important part in one's employability. Teamwork, effective communication, adaptability to change, positive and flexible attitudes, continuous learning, self-confidence, willingness to take risks, and a commitment to personal excellence are all employability characteristics of a successful worker.

The dynamic capabilities view and employability of employee has emerged as an attempt to untangle the complex problem of sustainable competitive ad- 
vantage in today's dynamic environment (Eisenhardt $\&$ Martin 2000). Some results of the empirical study show that dynamic capabilities have a significant positive impact on competitive advantage and that environment dynamism is an important driver. Dynamic capabilities enable firms to create, develop and renew the resources they have and capabilities for sustainable competitive advantages. All firms are pursuing a resource-based strategy of developing useful technology assets, habitual protection, and higher employability to maintain an important competitive advantage.

\section{AQIQOH NURUL HAYAT BACKGROUND}

The object for this study is a social organization (i.e. foundation) namely Nurul Hayat foundation, located in Surabaya, East Java, Indonesia that focuses in empowering and assisting orphans also poor people in the grass root level. This foundation adheres to a specific commitment to the community and has specific differentiation with another similar foundation, especially in a promising statement. This foundation promises that the money from donors will be used $100 \%$ for orphan programs which signify that all financial requirements for employees such as salary, benefits, empowerment programs, work tools, facilities, and allowances must be separated from the donated money. In order to support and afford the financial requirements and wealth program, Nurul Hayat manages several business activities. The biggest business activity is called Aqiqah business service which enables the foundation to sell more than three thousand goats monthly. Goats can be processed into profitable culinary business, like "satay and curry (sate and gulai)". The main office of Aqiqah Nurul Hayat is located in Surabaya with branch offices in 65 cities nationwide. Now, Aqiqah Nurul Hayat is known as a market leader in Indonesia.

\section{RESEARCH QUESTION}

The research questions are as follows:

a. What are the outcomes of HR empowerment program to improve the employability skills of every HR for the daily and future prospect of Aqiqah Nurul Hayat business service, Surabaya?

b. What are some specific programs held by Nurul Hayat Foundation in preparing HR as a dynamic capability resources to become the source of sustainable competitive advantage?

\section{RESEARCH METHODS}

The approach used in this research was the qualitative approach of inductive theory building through a single case study (Eisenhardt \& Martin 2000) and this single-case research was expected to exploit significant phenomena under extreme conditions. the data collection method used multiple sources. Multiple data sources were required to support the validity and reliability of the data obtained. There were 6 sources of case study data namely documents, records, interviews, direct observation, participant observation, and physical devices. The use of multiple data sources and instruments was also intended for triangulation purposes, i.e. cross checks to improve the accuracy level of data. The data analysis procedure was done in 3 steps through in-depth interview, observation, and document analysis.

\section{RESULTS AND DISCUSSION}

Some efforts done by Nurul Hayat Foundation management to strengthen the existence of Aqiqah Nurul Hayat business services are enhancing HR Empowerment program to improve HR employability concerning their competencies and whether to encourage the climate of trust within the organization, enable to trigger all individuals as HR employability to have self awareness to do better with innovation approach. (please check this sentence and how it is connected to the next sentence) There are (1) Creative Team Forum Establishment. In this forum, every HR learns to remove obstacles, to be creative, use brainstorming technique effectively, and respond positively to each other's ideas. There are a lot of new and fantastic ideas resulted from the creative team. The general improvement in employability attributes consists of (a) Essential attributes, such as basic social skills; honesty and integrity; basic personal presentation; reliability; willingness to work; understanding of actions and consequences; positive attitude to work; responsibility; self-discipline. (b) Personal competencies, such as proactivity; diligence; self-motivation; judgment; initiative; assertiveness; confidence; autonomous action. (c) Key transferable skills, such as reasoning; problem solving; adaptability; work-process management; teamwork; personal task and time management; functional mobility; basic ICT skills; basic interpersonal and communication skills; emotional and aesthetic customer service skills and (d) High level transferable skills, such as teamwork; business thinking; commercial awareness; continuous learning; vision; jobspecific skills; enterprise skills. (2) Organization 
and Work Culture. The HR empowerment program in Nurul Hayat has been implemented concurrently, especially to improve and enhance the employability level of all Nurul Hayat employees. Some decisions held by Nurul Hayat management to color the work culture are (a) Autonomy and (b) Supervisory Encouragement. (3) Career Resilience in Nurul Hayat. Career resilience is the ability to adjust to a career change as it happens and by extension, and to adapt to what the market demands. The purpose of this program is to (a) demonstrate a commitment to personal excellence, (b) accept changes as an opportunity for growth and challenge, (c) become a lifelong learner, (d) cultivate personal and professional relationships.

\section{REFERENCES}

Barney, J.B. 1991. Firm resources and sustained competitive advantage. Journal of Management 17(1): 99-120.

CBI (CONFEDERATION OF BRITISH INDUSTRY). 1999. Making Employability Work: An Agenda for Action. London: CBI.

Eisenhardt, K.M. \& Martin, J. 2000. Dynamic Capabilities: What are they? Strategic management Journal 21 (10/11): $1105-1121$

Fong, L.L., Sidhu, G.K. \& Fook, C.Y. 2014. Exploring 21st Century Skills among Postgraduates in Malaysia. Procedia - Social and Behavioral Sciences 123: 130-138. doi:10.1016/j.sbspro.2014.01.1406

Grant, R.M. 1996. Toward a knowledge-based theory of the firm. Strategic Management Journal. Summer Special Issue 17: 109-122.

Howieson, C., Mckechnie, J. \& Semple, S. 2012. Working pupils: Challenges and potential. Journal of Education and Work 25(4):37-41. doi:10.1080/13639080.2012.708723

Kogut, B. 1996. What firms do? Coordination, identity, and learning. Organization Science 7(5): 502-518.

Peteraf, M.A. 1993. The cornerstones of competitive dynamic capabilities advantage. Strategic Management Journal 14(3): 179-191.

Sattar, M., Rose, A., Norhaini, A. \& Puvanasvaran A.P. 2012. Employability Skills Assessment Tool Development. International Education Studies 5(5): 43-56. doi:10.5539/ies.v5n5p43

Sahandri, M., Hamzah, G.B., Mohamed, H. \& Abdullah, S.K. 2012. The Scenario from an Employer Perspective: Employability Profiles of Graduates. US-China Education Review 7: 675-681.

Schreuder, AMG., \& Coetzee, M. 2011. Careers: An organisational perspective. 4th ed. Cape Town: Juta.

Stiwne, E.E. \& Jungert, T. 2010. Engineering students' experiences of transition from study to work. (January 2015): $37-$ 41. doi:10.1080/13639080.2010.515967

Teece, D.J., Pisano, G. \& Shuen, A. 1997. Dynamic capabilities and strategic management. Strategic Management Journal 18(7): 09-533.

Yahya, M.K., Sukri, M., Syed, S.M.S. \& Haszlinna, N. 2013. Employability Skills Element's: Difference Perspective between Teaching Staff and Employers Industrial in Malaysia. Procedia - Social and Behavioral Sciences 93:15311535. doi:10.1016/j.sbspro.2013.10.077 